\title{
Peningkatan Pengetahuan Ibu Hamil Tentang Skrinning HIV/AIDS Melalui Audiovisual di Wilayah Kerja Puskesmas Andalas
}

\author{
Gina Muthia ${ }^{1}$, Eka Putri Primasari ${ }^{2}$, Putri Nelly Syofiah ${ }^{1}$ \\ ${ }^{1}$ Prodi Kebidanan Program Sarjana dan Pendidikan Profesi Bidan Program Profesi, STIKes \\ MERCUBAKTIJAYA Padang, Jl. Jamal Jamil Pondok Kopi Siteba Padang \\ ${ }^{2}$ Prodi DIII Kebidanan, STIKes MERCUBAKTIJAYA Padang, \\ Jl. Jamal Jamil Pondok Kopi Siteba Padang \\ E-mail: ginamuthia@mercubaktijaya.ac.id
}

\begin{abstract}
Abstrak - Selain mencegah terjadinya masalah pada ibu hamil dan bayinya, tujuan kualitas pelayanan antenatal adalah untuk mendeteksi dini munculnya masalah tersebut dan menghindari dampak negatifnya terhadap kesehatan. Hal ini termasuk infeksi HIV. Prevalensi HIV pada ibu hamil diproyeksikan meningkat dari 0,38\% (2012) menjadi 0,49\% (2016). Data ibu hamil terinfeksi HIV di Puskesmas Andalas tahun 2017 berada pada kisaran 1.600. Diketahui data pelaksanaan VCT di Puskesmas Andalas, tahun 2017 (Januari - Jun 2017) tercatat baru 250 pasien VCT, yang terdiri dari 224 orang ibu hamil dan 26 orang yang bukan ibu hamil, artinya di wilayah kerja Puskesmas Andalas hanya 14\% ibu hamil yang berpartisipasi untuk melakukan pemeriksaan HIV (VCT). Oleh karena itu diperlukan adanya kegiatan pengabdian masyarakat untuk meningkatkan pengetahuan tentang skrining HIV/AIDS pada ibu-ibu hamil. Hasil kegiatan berupa penyuluhan kepada 6 orang ibu hamil dari 10 orang sasaran yang ada di Pustu Sarang Gagak Kelurahan Andalas Padang. Luaran berupa publikasi artikel di jurnal pengabdian masyarakat yang ber E-ISSN dan terakreditasi nasional, sosial media dan peningkatan pengetahuan tentang skrinning HIV/AIDS dari ibu hamil.
\end{abstract}

Kata Kunci - Skrinning HIV/AIDS, Ibu Hamil, VCT

\begin{abstract}
In addition to preventing problems for pregnant women and their babies, the aim of quality antenatal care is to detect the emergence of these problems early and avoid negative impacts on health. This includes HIV infection. HIV prevalence in pregnant women is projected to increase from $0.38 \%$ (2012) to $0.49 \%$ (2016). Data for pregnant women infected with HIV at Puskesmas Andalas in 2017 was in the range of 1,600. It is known that data on the implementation of VCT at Puskesmas Andalas, in 2017 (January - Jun 2017) there were only 250 VCT patients, consisting of 224 pregnant women and 26 non-pregnant women, meaning that in the working area of the Andalas Puskesmas only 14\% of pregnant women participated to do an HIV test (VCT). Therefore, it is necessary to have community service activities to increase knowledge about HIV / AIDS screening in pregnant women. The results of the activity were counseling to 6 pregnant women from 10 target people in the Pustu Sarang Gagak Andalas Village, Padang. The output is in the form of publication of articles in public service journals that are E-ISSN and nationally accredited, social media and increasing knowledge about HIV / AIDS screening of pregnant women.
\end{abstract}

Keywords - HIV / AIDS screening, Pregnant Women, VCT

\section{PENDAHULUAN}

Pelayanan kesehatan berkualitas yang diberikan kepada ibu mulai dari hamil, melahirkan, dan nifas adalah indikator optimal kesehatan masyarakat. Ini menjamin terjadinya kelahiran bayi secara selamat. Human Immunodeficiency Virus (HIV) adalah retrovirus yang menyerang komponen-komponen utama sistem kekebalan, terutama T-sel CD4 positif dan makrofag. Akibatnya adalah sistem kekebalan tubuh yang terus menerus melemah [1]. Infeksi HIV dan Aquired Immunity Deficiency Syndrome (AIDS) adalah salah satu faktor yang dapat menghalangi kesehatan ibu dan bayi [2].
Bayi yang baru dilahirkan bisa terinfeksi virus HIV yang ditularkan dari ibu saat masih dalam kandungan melalui plasenta. Hal ini tidak banyak diketahui ibu hamil. Informasi tentang pemeriksaan HIV/AIDS bagi ibu hamil tidak banyak tersampaikan. Skrining HIV juga bisa ditolak dilakukan ibu hamil saat kunjungan pertama (K1) di Puskesmas. [3]. Lebih dari 90\% bayi tertular dari ibu yang menderita HIV selama rentang kehamilan hingga menyusui [4]. Infeksi HIV pada neonatal terjadi akibat penularan dari ibu kepada janin selama dalam kandungan atau saat periode intrapartum atau periode postpartum. [1]. 
Data dari Kementerian Kesehatan Republik Indonesia menyatakan bahwa sebaran kasus HIV/AIDS ada di 368 dari 497 kabupaten/kota seluruh Indonesia. Sejumlah 26.527 (90\%) penduduk usia reproduksi (15-49 tahun) dimana 12.279 diantaranya adalah perempuan, merupakan kasus baru di tahun 2013. Dari 12.279 tersebut terdapat 429 (15\%) berada pada kelompok ibu rumah tangga dan apabila ibu tersebut hamil maka akan berpotensi menularkan HIV kepada bayi yang dilahirkannya. [4].

Jumlah penderita HIV dan AIDS di Sumatera Barat pada tahun 2016 adalah 1.192 dan 1.515. [5]. Jumlah kasus HIV di Kota Padang tahun 2016 adalah 300 kasus dengan rincian 227 lelaki dan 73 wanita. Di tahun yang sama jumlah ibu hamil di Kota Padang adalah 18.511 orang ibu hamil dimana 875 orang $(4,72 \%)$ telah melakukan tes HIV secara sukarela dan didapatkan 9 orang $(1,02 \%)$ positif HIV. Jumlah ibu hamil di Puskesmas Andalas pada tahun 2017 adalah berkisar 1600 orang dimana yang telah melakukan pemeriksaan VCT adalah 224 orang pada bulan Januari-Juni 2017 artinya dari keseluruhan jumlah ibu hamil yang ada hanya $14 \%$ yang melakukan pemeriksaan HIV (VCT). [6]. Salah seorang petugas kesehatan di Puskesmas Andalas mengatakan bahwa yang tidak melakukan pemeriksaan HIV tersebut dikarenakan tidak tahu pentingnya deteksi dini HIV dan merasa baik-baik saja karena suami mereka tidak pernah gonta ganti pasangan. Berdasarkan fenomena tersebut maka perlu meningkatkan pemahaman ibu hamil tentang pentingnya deteksi dini HIV yang dilakukan melalui kegiatan pengabdian masyarakat.

\section{SOLUSI PERMASALAHAN}

Solusi yang ditawarkan untuk menyelesaikan masalah adalah meningkatkan pengetahuan ibu hamil tentang skrinning HIV/AIDS melalui teknik audio visual.

\section{METODE PELAKSANAAN}

Pelaksanaan program pengabdian masyarakat ini dimulai dengan koordinasi pihak Pustu dan bidan pembina wilayah. Tahapan kegiatan yang dilakukan sebagai berikut :

a. Melakukan observasi dan pengambilan data awal mengenai target sasaran dan tempat kegiatan tempat pelaksanaan kegiatan

b. Melakukan koordinasi dengan Puskesmas setempat, bidan desa dan kader untuk membantu lokalisasi keberadaan ibu hamil yang menjadi sasaran kegiatan yaitu di Pustu Sarang Gagak.

c. Pengabdi menyampaikan materi pentingnya Skrining HIV/AIDS bagi kesehatan ibu hamil dan bayi d. Pengabdi melakukan posttest kepada sasaran ibu hamil terkait dengan materi yang sudah disampaikan

e. Tim pengusul melibatkan peran serta mahasiswa dalam membantu kelancaran program yang akan dilaksanakan serta dapat menambah wawasan mahasiswa untuk menerapkan ilmunya secara langsung di lapangan.

\section{HASIL DAN PEMBAHASAN}

Target pelaksanaan kegiatan pengabdian masyarakat ini adalah peningkatan pengetahuan tentang pentingnya skrinning dalam upaya pencegahan penularan HIV/AIDS pada ibu hamil. Nantinya diharapkan semua ibu hamil di Pustu Sarang Gagak mau melakukan pemeriksaan HIV/AIDS di puskesmas saat kunjungan pertama (K1).

Kegiatan pengabdian ini dilaksanakan dengan memberikan penyuluhan kepada ibu hamil yang diawali dengan pre test, pemberian materi tentang Gambaran Perkembangan Kasus HIV/AIDS di Indonesia oleh Eka Putri Primasari, SKM, M.Kes, materi tentang Pentingnya Pencegahan HIV/AIDS pada ibu hamil oleh Gina Muthia, S.SiT.,M. Keb, materi tentang Apa itu HIV, penyebabnya, bagaimana cara penularan dan pencegahannya oleh Putri Nelly Syofiah, S.SiT., M.Keb dan diakhiri dengan memberikan post test kepada ibu hamil tentang materi yang sudah diberikan

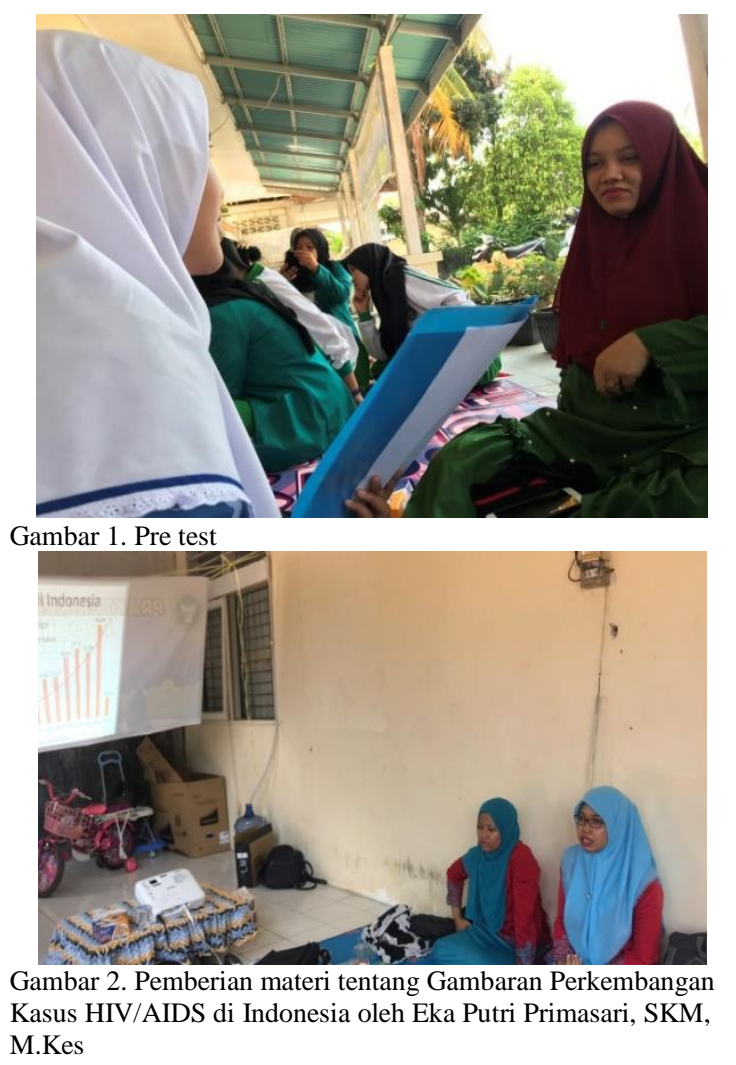




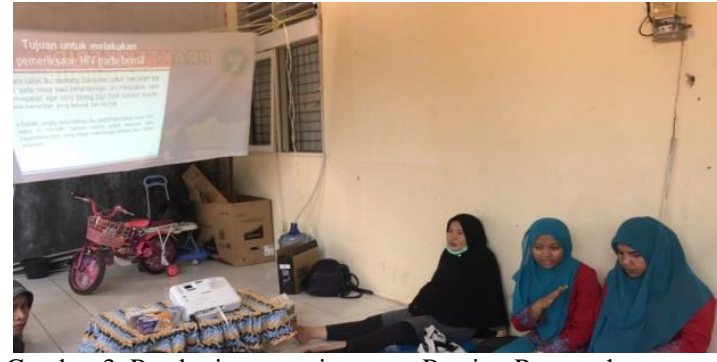

Gambar 3. Pemberian materi tentang Penting Pencegahan HIV/AIDS pada ibu Hamil oleh Gina Muthia, S.SiT., M.Keb

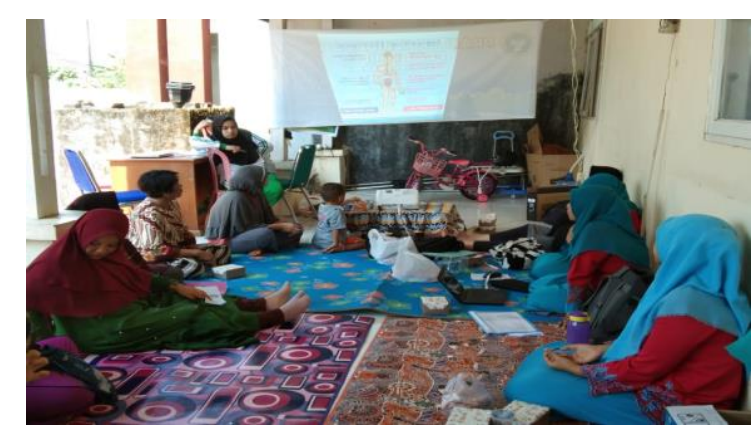

Gambar 4. Pemberian materi tentang Apa itu HIV, penyebabnya, bagaimana cara penularan dan pencegahannya oleh Putri Nelly Syofiah, S.SiT., M.Keb

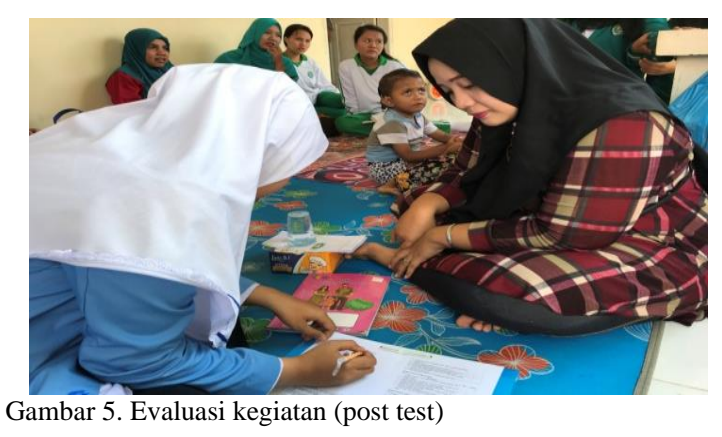

Evaluasi dari kegiatan ini adalah tim pengabdi memberikan post test kepada ibu hamil tentang materi yang sudah diberikan dengan hasil sebagai berikut :

Tabel 1. Tingkat pengetahuan ibu hamil tentang HIV sebelum

\begin{tabular}{lcccc}
\multicolumn{3}{c}{ dan sesudah pemberian materi } \\
\hline \multirow{2}{*}{ Pertanyaan } & \multicolumn{2}{c}{ Sebelum } & \multicolumn{2}{c}{ Setelah } \\
\cline { 2 - 5 } & org & $\%$ & org & $\%$ \\
\hline Pengertian HIV & 2 & 33,3 & 6 & 100 \\
Penyebab & 3 & 0,5 & 5 & 83,3 \\
Cara Penularan & 3 & 0,3 & 5 & 83,3 \\
Pencegahannya & 2 & 33,3 & 5 & 83,3 \\
\hline
\end{tabular}

\section{KESIMPULAN}

Kegiatan pengabdian kepada masyarakat terlaksana pada tanggal 15 November 2019 di Pustu Sarang Gagak, Wilayah Kerja Puskesmas Andalas dan berjalan dengan lancar. Kegiatan penyuluhan ini meningkatkan pengetahuan ibu hamil tentang pentingnya skrinning HIV/AIDS saat kunjungan pertama kehamilan.

\section{UCAPAN TERIMAKASIH}

Terima kasih disampaikan kepada Yayasan MERCUBAKTIJAYA, melalui LP2M STIKes MERCUBAKTIJAYA Padang yang telah mendanai kegiatan pengabdian masyarakat ini. Terima kasih juga disampaikan kepada Puskesmas Andalas khususnya ibu hamil di Pustu Sarang Gagak yang telah membantu terlaksananya kegiatan pengabdian masyarakat ini dengan lancar.

\section{DAFTAR PUSTAKA}

1. Heffner, Schust, 2020. Penyuluhan dan Pemeriksaan HIV pada Ibu Hamil sebagai Upaya Deteksi Dini Penularan dari Ibu Hamil ke Bayi di BPM $R$ Kecamatan Jagakarsa Jakarta Selatan, dalam Tiara Carolin, Bunga. Novelia, Sinta. (2010). BERNAS : Jurnal Pengabdian kepada Masyarakat Vol 1 No. 2

2. Departemen Keehatan RI, 2018. Hubungan Antara Sumber Informasi Tentang HIV/AIDS Dengan Pemeriksaan Pencegahan Penularan HIV Dari Ibu Ke Anak (PPIA) Di Puskesmas II Denpasar Selatan, dalam Sri Erawati, Ni Luh. Somoyani, Ni Ketut. Suindri, Ni Nyoman. (2007). Jurnal Ilmiah Kebidanan : The Journal of Midwifery Vol 6 No. 1

3. Cahyoningsih, Hermi. (2014). Hubungan Antara Pengetahuan Ibu Hamil Tentang HIV/AIDS dan Tes HIV/AIDS Secara Sukarela Dengan Sikap Tes HIV/AIDS Secara Sukarela Di Puskesmas Gedong Tengen Yogyakarta. http : //lib.unisayogya.ac.id

4. Kementrian Kesehatan RI,. (2012). Pedoman Pencegahan Penularan HIV dari Ibu ke Anak. Jakarta: Kementrian Kesehatan Repulblik Indonesia.

5. Info DATIN. (2016). Situasi dan Analisis HIV AIDS. Jakarta: Pusat Data dan Informasi Kementrian Kesehatan RI

6. DKK Padang. (2016). Laporan Bulanan Konseling, dan Tes HIV Sukarela (KTS/VCT). Padang: Dinas Kesehatan Kota Padang. 
Jati Emas (Jurnal Aplikasi Teknik dan Pengabdian Masyarakat)

Vol. 4 No. 2 Oktober 2020 - e. ISSN: 2550-0821 